\title{
Rapid light-induced changes in cell fluorescence and in xanthophyll-cycle pigments of Alexandrium excavatum (Dinophyceae) and Thalassiosira pseudonana (Bacillariophyceae): a photo-protection mechanism
}

\author{
Serge Demers ${ }^{1}$, Suzanne Roy ${ }^{2}$, Réal Gagnon ${ }^{1}$, Claudie Vignault ${ }^{2}$ \\ ${ }^{1}$ Institut Maurice-Lamontagne, Department of Fisheries and Oceans, 850 Route de la Mer, Mont-Joli, Québec, Canada G5H $3 Z 4$ \\ ${ }^{2}$ Centre Océanographique de Rimouski, INRS-Océanologie, 310 Allée des Ursulines, Rimouski, Québec, Canada G5L 3A1
}

\begin{abstract}
Studies of in vivo chlorophyll a (chl a) fluorescence per cell, measured with a flow cytometer, and the pigment composition of cultured phytoplanktonic cells suggested that the xanthophyll cycle plays a role in the prevention of photoinhibitory damage to the photosynthetic apparatus. Two species were tested: Alexandrium excavatum (Dinophyceae) and Thalassiosira pseudonana (Bacillariophyceae). Cells were grown under 3 acclimation light conditions: continuous low light $(50$ $\mu \mathrm{mol}$ photons $\left.\mathrm{m}^{-2} \mathrm{~s}^{-1}\right)$, continuous high light $\left(500 \mu \mathrm{mol}\right.$ photons $\left.\mathrm{m}^{-2} \mathrm{~s}^{-1}\right)$ and fluctuating light $(50,1000$, and $50 \mu \mathrm{mol}$ photons $\mathrm{m}^{-2} \mathrm{~s}^{-1}$; cycle frequency $=1 \mathrm{~h}^{-1}$ ). The time course of in vivo fluorescence per cell signal showed rapid decreases in fluorescence when cells were suddenly submitted to a continuous high light intensity $\left(1000 \mu \mathrm{mol}\right.$ photons $\left.\mathrm{m}^{-2} \mathrm{~s}^{-1}\right)$ for short periods of time (30 to $60 \mathrm{~min}$ ). This decrease was ca 50 to $65 \%$ of the initial fluorescence level. When the experimental light was turned off, fluorescence returned to a level generally close to its initial value. Concurrent with these rapid fluorescence decreases, the concentration of the epoxy-free pigment diatoxanthin increased at the expense of its parent compound, diadinoxanthin, upon exposure to high light. The process reversed when the light was turned off. Comparison among the 3 acclimation conditions suggests that fluorescence quenching is related to the concentration of diatoxanthin per unit chl $a$ in the same way for highlight- and low-light-acclimated cells. In addition to the fast, reversible reaction in pigments, the highlight-acclimated cells maintain a positive concentration of diatoxanthin even when kept in darkness for 1 to $2 \mathrm{~h}$. Low-light-acclimated cells lose their diatoxanthin fraction when put in the dark. Thus acclimation controls the long-term accumulation of the xanthophyll-cycle pigments in cells but it seems independent of the rapid reactions of the xanthophyll cycle that are related to fluorescence quenching. For both species, but particularly for $A$. excavatum, fluorescence quenching, resulting from light exposure and accompanied by xanthophyll pigment changes, suggests that non-radiative energy dissipation is taking place in the pigment bed, as in higher plants possessing an active xanthophyll cycle. This mechanism potentially allows algae to accomodate to rapid changes in the light field and permits cells to build up longer-term mechanisms of photoprotection such as regulation of pigment content and composition.
\end{abstract}

\section{INTRODUCTION}

Phytoplankton grow in very dynamic environments. As a result of hydrodynamic processes, they are exposed to large fluctuations in light intensity, over a wide range of time scales from seconds to hours (Dera \& Olszewski 1967, Legendre 1981, Demers et al. 1986). The physiological responses of algae serve as a buffer between the growth rate of the cell and the fluctuations of the external environment. These physiological responses to light fluctuations involve several mechanisms, observed as changes in the fluorescence yield (Kiefer 1973, Heaney 1978, Vincent 1979, 1980, Harris 1980a), the size and density of photosynthetic units and the composition and distribution of pigments (Halldal 1970, Chan 1978, Prézelin \& Sweeney 1978, Riper et al. 
1979. Falkowski \& Owens 1980, Perry et al, 1981, Sukenik et al. 1987), and the chemical composition as well as the activity level of photosynthetic enzymes (Beardall \& Morris 1976, Gibson 1978, Laws \& Bannister 1980, Falkowski \& Wirick 1981). These mechanisms do not all respond at the same rate (Harris 1980b). According to the hierarchical model of Harris (1980b), fluorescence is recognized to respond at very rapid time scales (10 to ca 1000 s), whereas pigment synthesis generally responds at time scales varying between hours and days. Sakshaug et al. (1987), using flow cytometry, demonstrated rapid (on the order of minutes) and reversible changes in the in vivo fluorescence per cell when diatom cells were transferred from low to high light intensities. They interpreted their data as a manifestation of a protective mechanism against strong light intensity. We show here that these rapid changes in the in vivo fluorescence per cell are associated with rapid and reversible changes in the concentration of particular carotenoid pigments taking part in the xanthophyll cycle. The cycle involves a light-driven reaction which transforms epoxy-containing xanthophylls (oxy-derivatives of carotenes) into epoxy-free pigments (Hager 1975). In higher plants and chlorophytes, the pigments involved in this cycle are violaxanthin, antheraxanthin and zeaxanthin (Hager 1975); the formation of zeaxanthin helps in the process of nonradiative dissipation of excess light energy (Demmig et al. 1987). In phytoplankton, equivalent reactions are found with the pigments diadinoxanthin and diatoxanthin (Hager 1975, Cunningham \& Schiff 1986). These latter pigments are present in the major groups of marine phytoplankton, diatoms, dinoflagellates and prymnesiophytes (Liaaen-Jensen 1978). We also show that the xanthophyll cycle is particularly active in 1 of the 2 species tested, Alexandrium excavatum, under light intensity conditions representative of the ocean euphotic zone, and that, in this species, photo-acclimation to low, high or fluctuating light regimes is reflected in the accumulation of the xanthophyll-cycle pigments and in the fluorescence variations upon exposure to excessive light.

\section{MATERIALS AND METHODS}

Alexandrium excavatum and Thalassiosira pseudonana, clone $3 \mathrm{H}$ (obtained from the Center for Culture of Marine Phytoplankton, Bigelow Laboratory, Boothbay Harbour, ME, USA) were grown at $18^{\circ} \mathrm{C}$ in batch cultures made from St. Lawrence estuary seawater ( $28 \%$ salinity) collected at the Maurice-Lamontagne Institute pumping system. Growth medium was enriched according to the ' $\mathrm{f} / 2$ ' recipe of Guillard \& Ryther (1962). Cultures were grown under 3 light con- ditions (250 W Super Metal Halide arc Iamp Optimarc TM, Duro-Test Electric Ltd, NJ, USA), referred to, in this text, as the acclimation conditions: continuous low light [photosynthetically active photon flux density (PPFD) $=50 \mu \mathrm{mol}$ photons $\mathrm{m}^{-2} \mathrm{~s}^{-1}$, continuous high light (PPFD $=500 \mu \mathrm{mol}$ photons $\mathrm{m}^{-2} \mathrm{~s}^{-1}$ ) and fluctuating light (light gradually increased within $30 \mathrm{~min}$ from 50 to $1000 \mu \mathrm{mol}$ photons $\mathrm{m}^{-2} \mathrm{~s}^{-1}$ and then gradually decreased to $50 \mu \mathrm{mol}$ photons $\mathrm{m}^{-2} \mathrm{~s}^{-1}$ over the next 30 $\min$; cycle frequency $=1 \mathrm{~h}^{-1}$ ). These conditions were chosen to resemble those for bottom- and top-euphoticzone cells and cells growing in dynamic environments, respectively, with changes in light conditions shorter than generation times. After 3 to $5 \mathrm{~d}$ of acclimation to the light conditions, experiments were carried out in the laboratory. During the experiments, the cultures were submitted to two or three 30 to $60 \mathrm{~min}$ cycles of exposure to high light followed by darkness. The cells were pre-darkened for $30 \mathrm{~min}$ before beginning the experiments to homogenize starting conditions among the cultures and to maximize fluorescence yield. A 300 $W$ projection bulb (Sylvania) was used as the experimental light; light intensity was generally $1000 \mu \mathrm{mol}$ photons $\mathrm{m}^{-2} \mathrm{~s}^{-1}$ except for one experiment where light was increased stepwise by changing voltage (no spectral change) from 50 to $1000 \mu \mathrm{mol}$ photons $\mathrm{m}^{-2} \mathrm{~s}^{-1}$ in 100 min. Temperature was regulated using a water bath into which the culture vessels were plunged.

Approximately every $5 \mathrm{~min}$, per cell in vivo fluorescence (excitation light: $424 / 44 \mathrm{~nm}$ band of a mercury lamp; collected emission: > $650 \mathrm{~nm}$ ) and Coulter cell volume were determined using a FACS Analyzer flow cytometer (Beckton-Dickinson, Mountain View, California). At least 2000 counts of fluorescent particles were used to generate the data set. The acquisition time was ca $30 \mathrm{~s}$ and the first measurement $\left(t_{0}\right)$ was done before the projection lamp was turned on.

At the beginning of the experiment (i.e. just before turning the experimental light on) and during the stable phases of the fluorescence signal, 200 to $400 \mathrm{ml}$ of the experimental culture were filtered onto Whatman GF/F glass-fiber filters and the pigments were extracted immediately with successive 1 to $2 \mathrm{ml}$ volumes of $100 \%$ acetone, HPLC-grade, until a further $1 \mathrm{ml}$ extraction of the residues showed undetectable concentration of pigments. Pigment composition and concentration were then analyzed by high performance liquid chromatography (HPLC), using the method developed by Mantoura \& Llewellyn (1983). A PerkinEImer Pecosphere RP 18, $3 \mu \mathrm{m}$ column, was used for separation. An 8 min gradient, starting with an 80:10:10 solution of methanol:water:ion-pairing solution (Mantoura \& Llewellyn 1983) and ending with an $80: 20$ solution of methanol:acetone, was followed by an isocratic hold until $13 \mathrm{~min}$. A Spectra Physics 8800 
pump controlled flow rate through the column $(1.5 \mathrm{ml}$ $\min ^{-1}$ ). Detection was done at $440 \mathrm{~nm}$ using a Spectra Physics SP 8490 UV-VIS detector. Identification and quantification were achieved using external pigment standards, TLC-prepared from Alexandrium excavatum or obtained commercially from Sigma (chlorophyll a, $\beta$-carotene).

\section{RESULTS}

Time courses of the in vivo fluorescence per cell signal showed rapid and reversible changes in fluorescence when cells of Alexandrium excavatum were submitted to high light intensity for short (generally 30 to $60 \mathrm{~min}$ ) periods of time (Fig. $1 \mathrm{~A}$ to $\mathrm{C}$ ). When the experimental light was turned on, a strong decrease in the fluorescence level was observed for all 3 cultures grown under different light acclimation. This decrease was about 50 to $65 \%$ of the initial fluorescence level (Table 1). When the experimental light was turned off, fluorescence returned to a level generally close to its initial value. However, the time taken to reach this level was longer than that for the fluores- cence decrease upon exposure to high light. Low-lightgrown cells exhibited higher fluorescence per cell under both light and dark treatments compared to high-light- or fluctuating-light-grown cells (Fig. $1 \mathrm{~A}$ to C, Table 1a). The percent change in fluorescence was lower in these low-light cells, compared with the other acclimation conditions. No changes in cell volume were noticed during any of the experiments.

Concurrent with these changes in cell fluorescence, the concentration of the epoxy-free pigment diatoxanthin increased at the expense of its parent compound, diadinoxanthin, upon exposure to high light (Fig. 1D to F, Fig. 2). Fig. 1A to $\mathrm{C}$ shows that a high proportion of diatoxanthin [expressed as the ratio diatoxanthin/ (diadinoxanthin + diatoxanthin) and reported in parentheses in Fig. 1] was always found following the light treatment, coincident with the low fluorescence values. The summed concentration of these 2 pigments showed little change through time during the lightdark experimental cycles (experiments lasting less than $6 \mathrm{~h}$ ) (Fig. 1D to F). Increasing the light intensity during the light portion of the experimental cycle (Fig. 1E) caused a further increase in diatoxanthin and a concurrent decrease in diadinoxanthin, at the same

$$
\begin{aligned}
& \text { LOW LIGHT } \\
& \left(50 \mu \mathrm{E} \mathrm{m}^{-2} \mathrm{~s}^{-1}\right)
\end{aligned}
$$
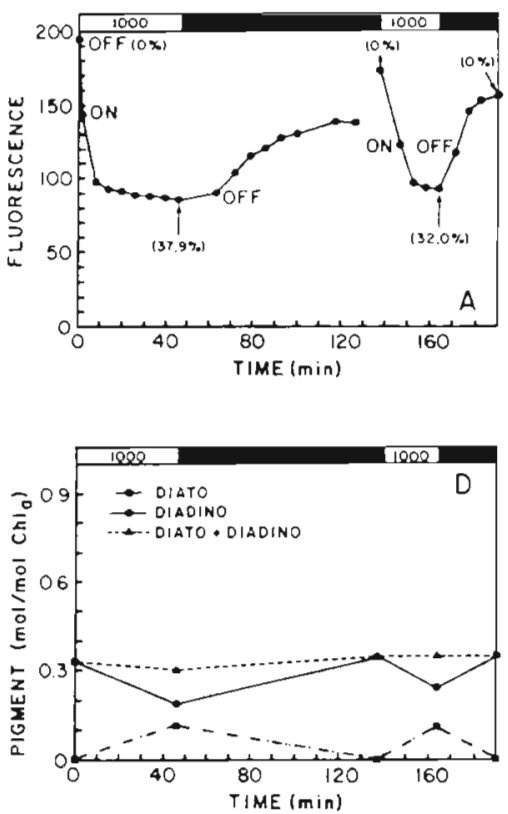

HIGH LIGHT

$\left(500 \mu \mathrm{E} \mathrm{m}^{-2} \mathrm{~s}^{-1}\right)$
FLUCTUATING LIGHT

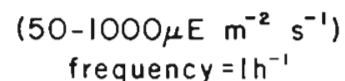

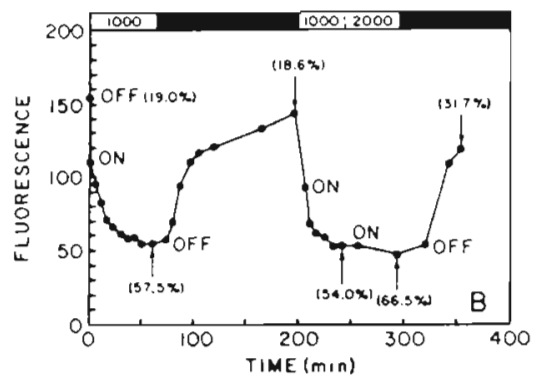
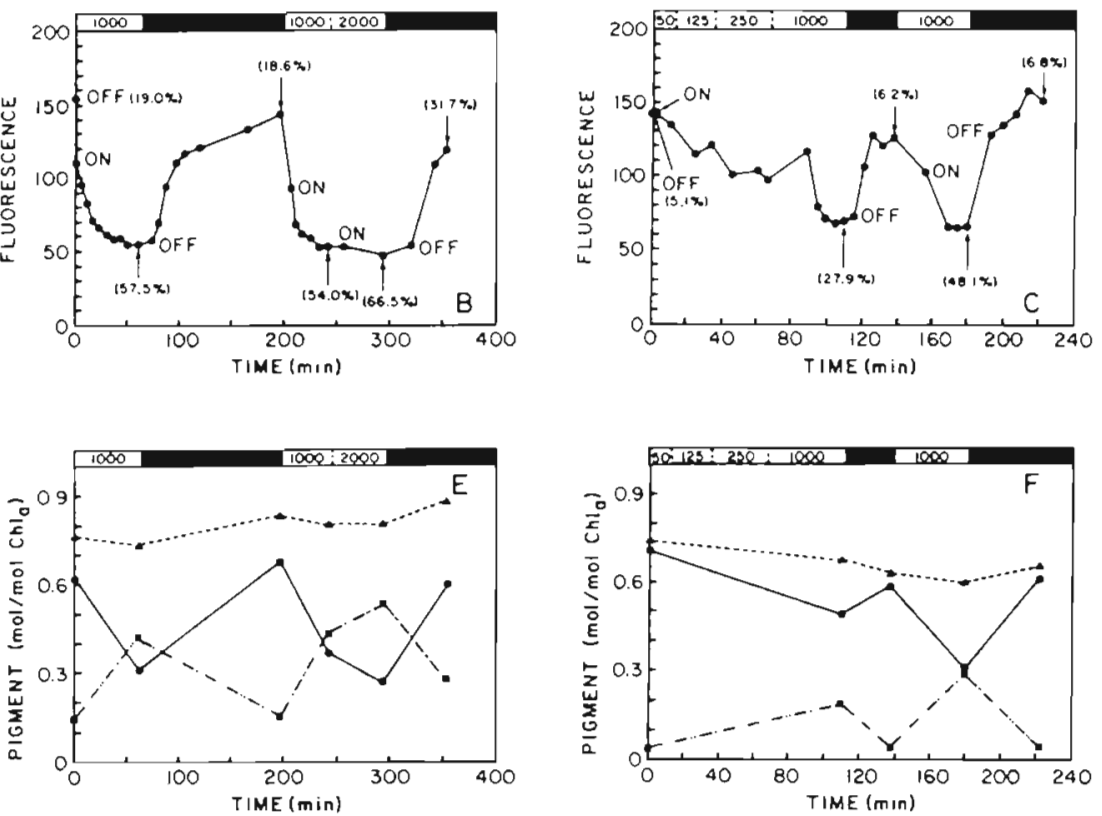

Fig. 1. Alexandrium excavatum. Changes over time in fluorescence (arbitrary units) of cells submitted to a short-term dark-light cycle, for cells acclimated to (A) continuous low light $\left(50 \mu \mathrm{mol}\right.$ photons $\left.\mathrm{m}^{-2} \mathrm{~s}^{-1}\right)$; (B) continuous high light (500 $\mu \mathrm{mol}$ photons $\mathrm{m}^{-2}$ $\left.\mathrm{s}^{-1}\right)_{i}$ (C) fluctuating light ( 50 to $1000 \mu \mathrm{mol}$ photons $\mathrm{m}^{-2} \mathrm{~s}^{-1}$; cycle frequency $=1 \mathrm{~h}^{-1}$ ). Percentages in parentheses $=$ diatoxanthin/ (diadinoxanthin + diatoxanthin) $\times 100$ for samples indicated by arrows. ON and OFF: light on and off. Panels $D$ to $F$ show the corresponding changes in the xanthophyll-cycle pigments ( $\mathrm{mol} \mathrm{mol}{ }^{-1} \mathrm{chl}$ a); DIATO: diatoxanthin concentration; DIADINO: diadinoxanthin concentration; DIATO + DIADINO: variations in the sum of diatoxanthin + diadinoxanthin. Numbers at top of panels: experimental light intensity ( $\left.\mu \mathrm{mol} \mathrm{m}^{-2} \mathrm{~s}^{-1}\right)$; black bars: light off 


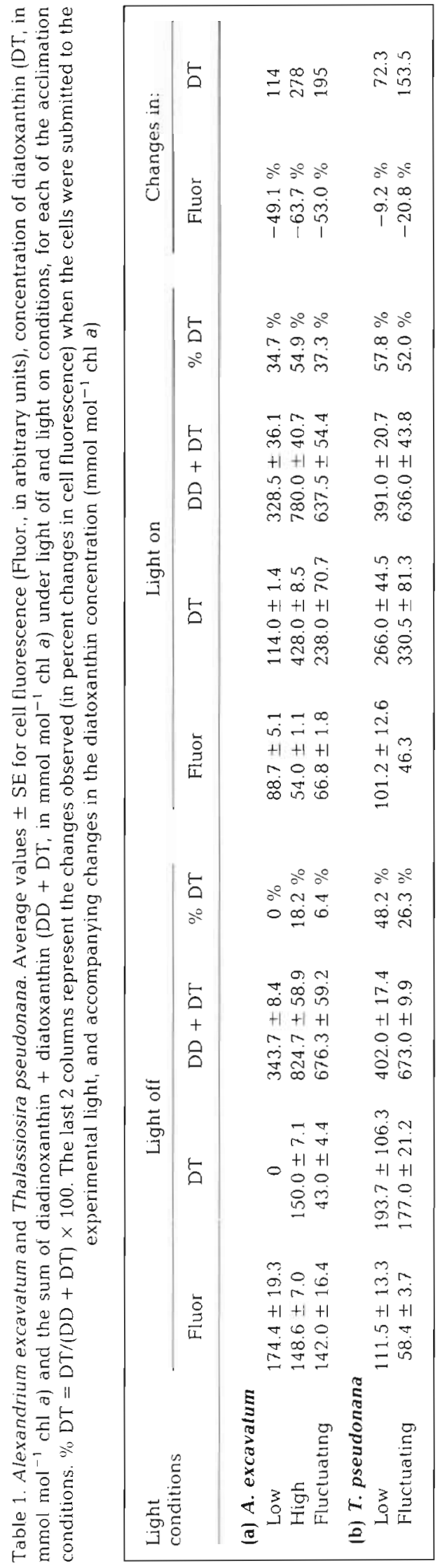

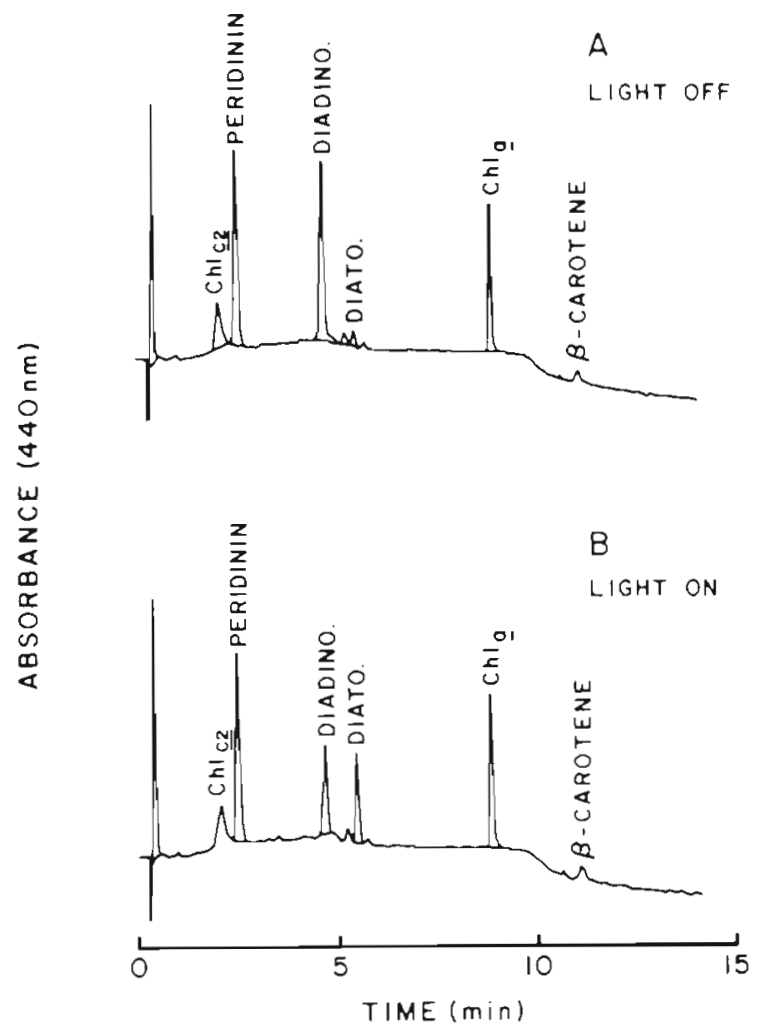

Fig. 2. Alexandrium excavatum. HPLC chromatogram showing pigment composition of cells submitted to (A) darkness and (B) high light intensity (1000 $\mu \mathrm{mol}$ photons $\mathrm{m}^{-2} \mathrm{~s}^{-1}$ ). (Note the low concentration of diatoxanthin (DIATO.) and the abundance of the diadinoxanthin (DIADINO.) pigment in darkness (A). Under high light intensity the diadinoxanthin concentration decreases drastically and the diatoxanthin concentration increases. The other pigments are not affected over this period]

time as fluorescence further decreased. Other pigments showed no change in concentration during these experiments.

Comparison among the 3 acclimation conditions showed that low-light cells (1) emit more fluorescence per cell, (2) exhibit a smaller decrease in fluorescence when treated with the experimental high light, (3) contain less xanthophyll-cycle pigments relative to chlorophyll a (chl a). (4) produce less diatoxanthin per unit chl $a$ upon exposure to the experimental high light, and (5) do not maintain background levels of diatoxanthin in darkness. The highest diatoxanthin concentration per unit chl a attained (for high-light-acclimated cells) represented $55 \%$ of the xanthophyll-cycle pigments. High-light-grown cells also contained the highest amount of diatoxanthin in darkness (Table 1a). Characteristics of cells grown under fluctuating light fall in between those of high-light- and low-lightgrown Alexandrium excavatum.

In the diatom species tested, Thalassiosira 
pseudonana, fluorescence per cell varied much less during exposure to the experimental high light and darkness cycles than with the other species (Fig. 3A, B, Table 1b). Associated with this lack of response in fluorescence, xanthophyll cycle pigments also showed smaller changes in their concentration (Fig. 3C, D, Table 1b). Comparison between the low-light- and the fluctuating-light-acclimated cells showed (1) higher fluorescence per cell and (2) lower concentration of the xanthophyll-cycle pigments relative to chl $a$ in low-lightgrown cells, as observed in the dinoflagellate species tested, and (3) very small changes in fluorescence or pigments in response to the experimental high light under both conditions. The high-light-grown culture was not tested; it was accidentally lost before the experiment.

\section{DISCUSSION}

\section{Pigment reactions}

The exact functions of the light-dependent xanthophyll conversions called the xanthophyll cycle have not been clearly identified. In higher plants, this cycle involves reactions with $\mathrm{NADPH}$, glutathione and dehydro-ascorbic acid (Hager 1980). Reduction energy is used up either directly during epoxidation or indirectly during de-epoxidation. This has led to the suggestion of a role in helping to rapidly trigger electron transport reactions upon illumination by oxidizing the electron acceptors (Hager 1975). Foyer \& Halliwell (1976) suggested that coupling of the de-epoxidation reactions with glutathione oxidation could indicate a potential regulation of the enzymes of the Calvin cycle, via glutathione. Yamamoto \& Takeguchi (1972) proposed that the xanthophyll cycle could have some regulatory effect on photosynthesis by influencing membrane properties. More recently, Demmig et al. (1987) suggested that formation of the epoxy-free pigment (zeaxanthin in higher plants) was indicative of a specific function of this compound in the prevention of photoinhibitory damage. Demmig-Adams et al. (1989) considered that this pigment could mediate radiationless energy dissipation by creating quenching centers for excessive light in the antennae. Recent work with higher plants (Adams et al. 1990 and references therein) provide evidence that this xanthophyll-cycleassociated dissipation process prevents sustained inactivation of photochemistry by excessive light (= photoinhibitory damage) and that it is reflected in a decrease in fluorescence resulting from re-routing of excitation energy.

The pigments involved in the xanthophyll cycle of higher plants are, however, absent from many of the dominant marine planktonic algae (diatoms, dinoflagellates, prymnesiophytes). In these algae, another xanthophyll, diadinoxanthin, seems to be associated with a similar epoxide cycle (involving diadinoxanthin and diatoxanthin) which has been suggested to play a role similar to that of the xanthophyll cycle of higher

$$
\begin{aligned}
& \text { LOW LIGHT } \\
& \left(50 \mu \mathrm{E} \mathrm{m}^{-2} \mathrm{~s}^{-1}\right)
\end{aligned}
$$

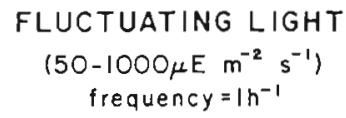

Fig. 3. Thalassiosira pseudonana (clone $3 \mathrm{H})$. Changes over time in fluorescence (arbitrary units) of cells submitted to a short-term dark-light cycle, for cells acclimated to (A) continuous low light (50 umol photons $\mathrm{m}^{-2} \mathrm{~s}^{-1}$ ) and (B) fluctuating light (50 to $1000 \mu \mathrm{mol}$ photons $\mathrm{m}^{-2} \mathrm{~s}^{-1}$; cycle frequency $=1 \mathrm{~h}^{-1}$ ). Percentages in parentheses = diatoxanthin/(diadinoxanthin + diatoxanthin) $\times 100$ for samples indicated by arrows. Panels $C$ and $D$ show the corresponding changes in the xanthophyll-cycle pigments $\left(\mathrm{mol} \mathrm{mol} \mathrm{m}^{-1}\right.$ chl $a_{\text {; }}$ lines and symbols as in Fig. 1D. (High-light-grown culture missing; it was accidentally lost before the experiment)
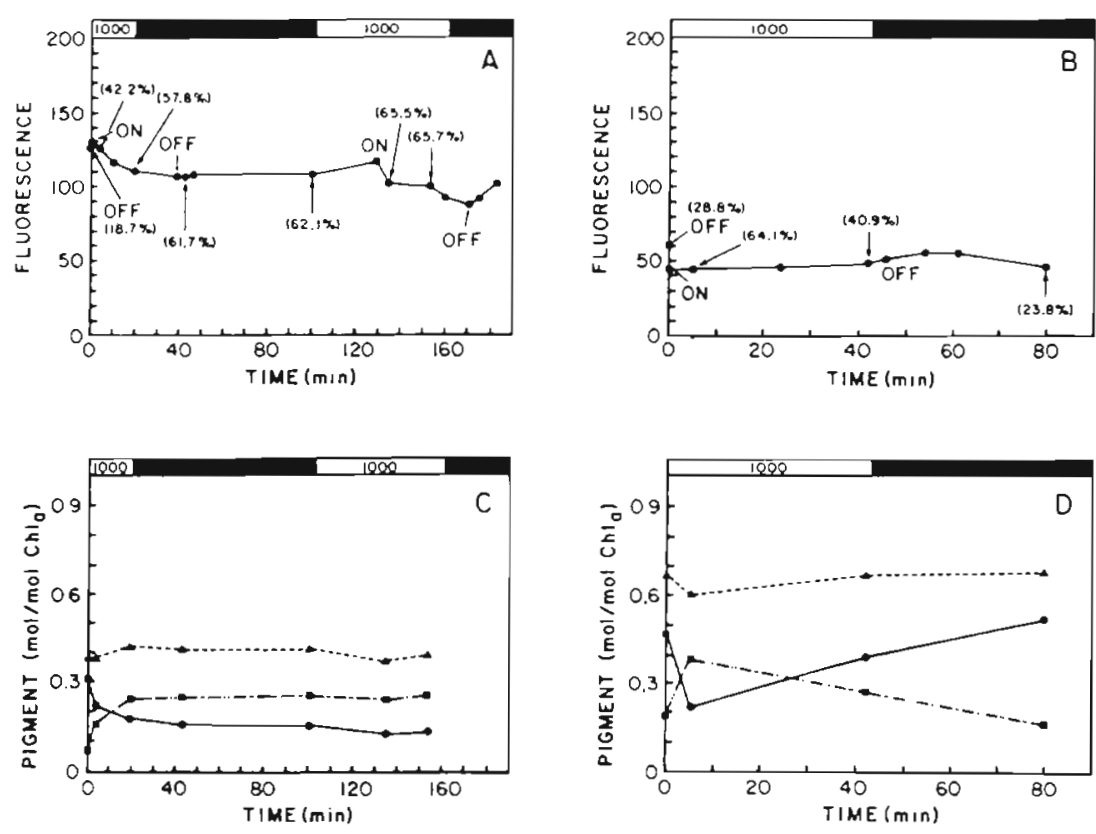
plants (Cunningham \& Schiff 1986, Sakshaug et al. 1987). Diadinoxanthin also plays a role as light-harvester in some algae (Haxo et al. 1984, Owens et al. 1987). Different pools of this pigment may be devoted to these 2 functions.

Results obtained here show that exposure to high irradiance stress rapidly (30 to $60 \mathrm{~min}$ ) and reversibly transforms a fraction of the diadinoxanthin pool of Alexandrium excavatum into diatoxanthin, with no other concurrent changes in pigment concentration. No new pigment synthesis is involved. This suggests that a diadinoxanthin-based xanthophyll cycle is active in this dinoflagellate. Increasing the irradiance brings about an increased transformation of diadinoxanthin into diatoxanthin (Fig. 1E). Co-occurrence with fluorescence quenching suggests that this xanthophyll cycle is related to photo-protection, as observed in higher plants.

Comparison among low-light, high-light and fluctuating-light acclimation for Alexandrium excavatum shows that, on a scale of 3 to $5 \mathrm{~d}$, cellular pigment concentration adjusted to the light conditions used for growth. Besides the well-known decrease (Falkowski \& Owens 1980) in chl a and cobserved in high-lightgrown cells compared to low-light-grown ones $\left(7.8 \times 10^{-15} \mathrm{~mol} \mathrm{chl}\right.$ a cell ${ }^{-1}$ in high light, $24.1 \times 10^{-15}$ mol chl a cell ${ }^{-1}$ in low light, for $A$. excavatum), an increase in xanthophyll cycle pigments relative to $\mathrm{chl}$ a was observed under high or fluctuating light conditions (Fig. 1E, F). This is consistent with their proposed role as photo-protective pigments; the brighter the light to which cells are exposed, the more they synthesize these pigments. Acclimation to high light has been observed, in many algae, to favor accumulation of other carotenoids, of the $\beta$-carotene type (Falkowski \& LaRoche 1991). These pigments, as do the xanthophyll pigments discussed here, absorb light but do not transfer excitation energy to the reaction centers.

Acclimation to specific light conditions is also reflected in the background (dark) level of the potentially photo-protective pigment, diatoxanthin. Highlight-acclimated cells maintain a positive concentration of diatoxanthin even when kept in darkness for 1 to $2 \mathrm{~h}$ (Fig 1E, F). Low-light-acclimated cells lose their diatoxanthin fraction when put in the dark (Fig. 1D). Thus, algae possessing large quantities of this pigment involved in the xanthophyll cycle should, as in higher plants (Demmig et al. 1987), be better equipped for protection against high light.

In dinoflagellates, diadinoxanthin often makes up 20 to $30 \%$ of total carotenoids (Jeffrey et al. 1975). This fraction is more important than that in the higher plants tested by Demmig et al. (1988) and Demmig-Adams et al. (1989). This higher concentration of potentially light-protective xanthophylls may be related to the more substantial environmental fluctuations facing phytoplankton cells compared to higher plants (Powles 1984). This may be even more pronounced for dinoflagellate species, known to be sensitive to high light exposure (Richardson et al. 1983). The lack of response in the diatom species tested here may indicate that the light conditions used were not actually stressful, since, in the study of Sakshaug et al. (1987), exposure to a higher light intensity brought about rapid and reversible changes in fluorescence similar to the ones observed here for Alexandrium excavatum. This would agree with the suggestion of Richardson et al. (1983) that dinoflagellates experience photoinhibition at relatively low irradiances whereas diatoms can tolerate higher-light environments before applying photo-protective mechanisms.

\section{Fluorescence variations}

Decreases in the fluorescence yield upon exposure to high irradiance have been reported before (Kiefer 1973, Vincent 1980, Sakshaug et al. 1987, Neale et al. 1989). These changes have been related to the effects of photoinhibition, defined as a reduction of photosynthetic capacity induced by exposure to visible light (Powles 1984). However, as discussed by Demmig et al. (1987), photoinhibition may result from 2 different mechanisms. The first is photo-damage to the Photosystem II (PS II) reaction centers. This leads to an increase in fluorescence yield, more often measured as a rise in the initial fluorescence $\left(F_{0}\right)$ during kinetics measurements, reflecting a decrease in the rate constant for PS II photochemistry. In this case, the rate of photosynthesis should be affected and a permanent or semi-permanent decrease in the photosynthetic capacity should be observed (Bilger \& Björkman 1990). The second mechanism is based primarily on an inactivation of electron transport in the thylakoids which leads to an alteration of the reaction center of PS II. This alteration results in a decrease in the primary photochemical efficiency, and the process is reversible. This dissipation of excitation energy via pathways other than photochemistry leads to fluorescence quenching (Vincent et al. 1984, Demmig et al. 1987). In that case, photosynthetic capacity should not be affected (Bilger \& Björkman 1990).

Various mechanisms have been proposed to explain the quenching of fluorescence (Vincent et al. 1984). Bilger \& Björkman (1990) suggest the following: (1) dissipative cyclic electron flow around PS II (Falkowski et al. 1988); (2) dissipation of excitation energy by conversion of PS II centers (Weis \& Berry 1987); (3) a cycle in which hydrogen peroxide acts as an electron acceptor (Neubauer \& Schreiber 1989); (4) increased 
'spill over' of energy of excitation from PS II to PS I which results in a decreased fluorescence yield (Ögren $\&$ Öquist 1984); (5) dissipation of non-radiative energy in the pigment bed (Björkman 1987, Demmig \& Björkman 1987, Demmig et al. 1987). As pointed out by Krause (1988), these altered PS II centers still act as efficient excitation traps. The trapped energy is converted to heat, which leads to a decrease in the fluorescence yield. This increase in thermal de-excitation acts as an overflow valve to allow nondestructive dissipation of excess excitation energy (Demmig et al. 1987). This process is viewed as an efficient protective mechanism.

In the present study, fluorescence quenching resulting from light exposure, accompanied by xanthophyll pigment changes, suggests that dissipation of nonradiative energy is taking place in the pigment bed, as in higher plants possessing an active xanthophyll cycle. Similarity in the reactions observed suggests that this process could help prevent photoinhibitory damage in phytoplankton cells. Fluorescence changes obtained here resemble those reported by Vincent et al. (1984) in a study of phytoplankton from a lake surface. Their results were interpreted as a reversible inactivation of reaction centers PS II, leading to an increase in nonradiative dissipation, as is suggested here.

Comparison among the 3 acclimation conditions tested here suggests that in Alexandrium excavatum, fluorescence quenching, corrected for the cell concentration of chl $a_{\text {, is }}$ is rated to the diatoxanthin concentration (per unit chl a) in the same way (same slope) for

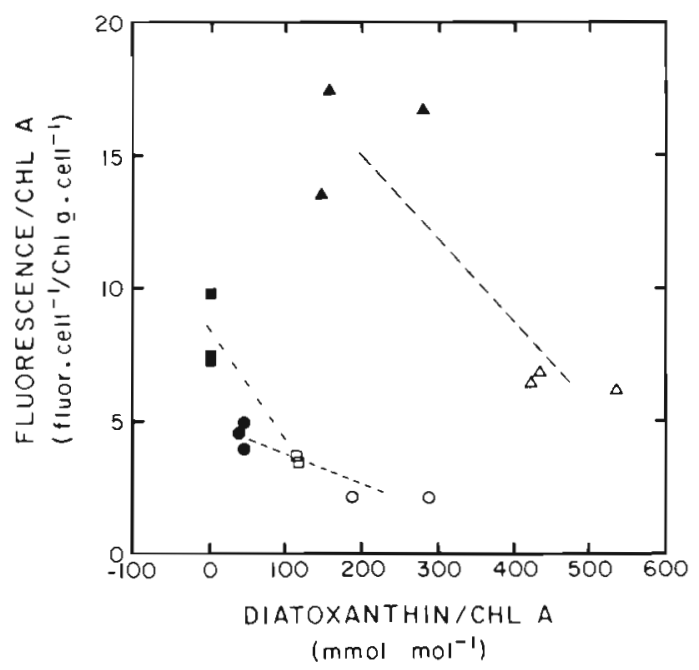

Fig. 4. Alexandrium excavatum. Changes in cell fluorescence (arbitrary units $\mathrm{mol}^{-1} \mathrm{chl}$ a) associated with those of diatoxanthin concentrations ( $\mathrm{mol} \mathrm{mol}{ }^{-1} \mathrm{chl}$ a). Closed symbols are for light off conditions and open symbols for light on. $(\boldsymbol{\omega}, \square)$ Lowlight-acclimated cells; $(\nabla, \Delta)$ high-light-acclimated cells; $(\bullet, 0)$ fluctuating-light-acclimated cells. Lines joining light off and light on points are drawn by eye high-light- and low-light-acclimated cells (Fig. 4). Thus acclimation controls the long-term accumulation of the xanthophyll-cycle pigments in the cells, but it seems independent of the rapid reactions of the xanthophyll cycle that are related to fluorescence quenching. It is not clear why the fluctuating-light-grown cells show a different pattern in Fig. 4. Perhaps exposure to 1000 $\mu \mathrm{mol}$ photons $\mathrm{m}^{-2} \mathrm{~s}^{-1}$ in the light-dark cycles does not constitute a light stress for cells that were grown between 50 and $1000 \mu \mathrm{mol}$ photons $\mathrm{m}^{-2} \mathrm{~s}^{-1}$. Further experiments are needed to elucidate this aspect.

What was termed the 'sunglass effect' in the study by Sakshaug et al. (1987) has an ecological significance. It allows algae to accomodate to rapid changes in the light field and permits cells to build up longer-term mechanisms of photoprotection such as regulation of pigment content and composition. Moreover, in the context of using photoadaptative responses of phytoplankton cells as an index of vertical mixing (Lewis et al. 1984, Cullen \& Lewis 1988, Therriault et al. 1990), an understanding of light-governed rapid changes in cellular fluorescence and reactions of photo-protective pigments could become useful tools in modelling vertical mixing.

Acknowledgements. We thank Drs J.-C. Therriault and M. Levasseur for fruitful discussions and Dr Stephen Bates for his comments on the manuscript. The help of $J$. Y. Couture is gratefully acknowledged. Support for this work was provided for S. R. from a NSERC individual grant. The UV-VIS HPLC detector was graciously made available to S. R. by Dr A. Cembella (MLI). This work is a contribution from the MauriceLamontagne Institute, Department of Fisheries and Oceans, Canada.

\section{LITERATURE CITED}

Adams, W W. III, Demmig-Adams, B, Winter, K. (1990). Relative contributions of zeaxanthin-related and zeaxanthin-unrelated types of 'high-energy-state' quenching of chlorophyll fluorescence in spinach leaves exposed to various environmental conditions. Plant Physiol. 92: 302-309

Beardall, J., Morris, I. (1976). The concept of light intensity adaptation in marine phytoplankton: some experiments with Phaeodactylum tricornutum. Mar. Biol. 37: 377-387

Bilger, W., Björkman, O. (1990). Role of the xanthophyll cycle in photoprotection elucidated by measurements of lightinduced absorbance changes, fluorescence and photosynthesis in leaves of Hedera canariensis. Photosynthesis Res. 25: $173-185$

Björkman, O. (1987). Low-temperature chlorophyll fluorescence in leaves and its relationship to photon yield of photosynthesis in photoinhibition. In: Kyle, D. J., Osmond, C. B., Arntzen, C. J. (eds.) Photoinhibition. Elsevier Science Publishers, Amsterdam, p. 123-144

Chan, A. T. (1978). Comparative physiological study of marine diatoms and dinoflagellates in relation to irradiance and cell size. I. Growth under continuous light. J. Phycol. 14: 396-402

Cullen, J. J., Lewis, M. R. (1988). The kinetics of algal photoadaptation in the context of vertical mixing. J. Plankton Res. 10: 1039-1063 
Cunningham, F. X. Jr, Schiff, J. A. (1986). Chlorophyll-protein complexes from Euglena gracilis and mutants deficient in chlorophyll b. I. Pigment composition. Plant Physiol. 80: $223-230$

Demers, S., Legendre, L., Therriault, J. C. (1986). Phytoplankton responses to vertical mixing. In: Bowman, M., Yentsch, C. M., Peterson, W. T. (eds.) Tidal mixing and plankton dynamics. Springer-Verlag, Berlin, p. 1-40

Demmig, B., Björkman, O. (1987). Comparison of the effect of excessive light on chlorophyll fluorescence $(77 \mathrm{~K})$ and photon yield of $\mathrm{O}_{2}$ evolution in leaves of higher plants. Planta 171: 171-184

Demmig, B., Winter, K., Krüger, A., Czygan, F.-C. (1987). Photoinhibition and zeaxanthin formation in intact leaves. Plant Physiol. 84: 218-224

Demmig, B., Winter, K., Krüger, A., Czygan, F.-C. (1988). Zeaxanthin and the heat dissipation of excess light energy in Nerium oleander exposed to a combination of high light and water stress. Plant Physiol. 87: 17-24

Demmig-Adams, B., Winter, K., Krüger, A., Czygan, F.-C. (1989). Zeaxanthin synthesis, energy dissipation, and photoprotection of photosystem II at chilling temperatures. Plant Physiol. 90: 894-898

Dera, J., Olszewski, J. (1967). On the natural irradiance fluctuations affecting photosynthesis in the sea. Acta geophys. pol. 15: 351-364

Falkowski, P. G., Kolber, Z., Fujita, Y. (1988). Effect of redox state on the dynamics of photosystem Il during steadystate photosynthesis in eukaryotic algae. Biochim. biophys. Acta 993: 432-443

Falkowski, P. G., LaRoche, J. (1991). Acclimation to spectral irradiance in algae. J. Phycol. 27: 8-14

Falkowski, P. G., Owens, T. G. (1980). Light-shade adaptation: 2 strategies in marine phytoplankton. Plant Physiol. 66: $592-595$

Falkowski, P. G., Wirick, C. D. (1981). A simulation model of the effect of vertical mixing on primary production. Mar. Biol. 65: 69-75

Foyer, C. H., Halliwell, B. (1976). The presence of glutathione and glutathione reductase in chloroplasts: a proposed role in ascorbic acid metabolism. Planta 133: 21-25

Gibson, C. E. (1978). Field and laboratory observations on temporal and spatial variation of carbohydrate content in planktonic blue-green algae in Lough Neagh, Northern Ireland. J. Ecol. 66: 97-115

Guillard, R. R. L., Ryther, J. H. (1962). Studies of marine planktonic diatoms. I. Cyclotella nana Hustedt, and Detonula confervacea (Cleve) Gran. Can. J. Microbiol. 8 229-239

Hager, A. (1975). Die reversiblen, lichtabhängigen Xanthophyllumwandlungen im Chloroplasten. Ber. dt. bot. Ges. Bd. 88: $27-44$

Hager, A. (1980). The reversible, light-induced conversions of xanthophylls in the chloroplast. In: Czygan, F-C. (ed.) Pigments in plants. Gustav-Fischer-Verlag, Stuttgart, p. $57-79$

Halldal, P. (1970). The photosynthetic apparatus of microalgae and its adaptation to environmental factors. In: Halldal, P. (ed.) Photobiology of microorganisms. Wiley, New York, p. $17-56$

Harris, G. P. (1980a). The relationship between chlorophyll a fluorescence, diffuse attenuation changes and photosynthesis in natural phytoplankton populations. J. Plankton Res. 2: 109-127

Harris, G. P. (1980b). Temporal and spatial scales in phytoplankton ecology. Mechanism, methods, models and management. Can. J. Fish. Aquat. Sci. 37: 877-900
Haxo, F. T., Neori, A., White, M. (1984). Photosynthetic action spectra of chloromonads. J. Protozool. 31: 25A

Heaney, S. I. (1978). Some observations on the use of the in vivo fluorescence technique to determine chlorophyll a in natural populations and cultures of freshwater phytoplankton. Freshwat. Biol. 8: 115-126

Jeffrey, S. W. Sielicki, M., Haxo, F. T (1975). Chloroplast pigment patterns in dinoflagellates. J. Phycol. 11.374-384

Kiefer, D. A. (1973). Fluorescence properties of natural phytoplankton populations. Mar. Biol. 22: 263-269

Krause, G. H. (1988). Photoinhibition of photosynthesis. An evaluation of damaging and protective mechanisms. Physiologia Plant. 74: 566-574

Laws, E. A., Bannister, T T. (1980). Nutrient- and light-limited growth of Thalassiosira fluviatilis in continuous culture, with implications for phytoplankton growth in the ocean. Limnol. Oceanogr 25: 457-473

Legendre, L. (1981). Hydrodynamic control of marine phytoplankton production: the paradox of stability. In: Nihoul, J. C. J. (ed.) Ecohydrodynamics. Elsevier, Amsterdam, p. 191-207

Lewis, M. R., Cullen, J. J., Platt, T (1984). Relationships between vertical mixing and photoadaptation of phytoplankton; similarity criteria. Mar. Ecol. Prog. Ser. 15: $141-149$

Liaaen-Jensen, S. (1978). Marine carotenoids. In: Scheuer, P. J. (ed.) Marine natural products. Academic Press, New York, p. 1-73

Mantoura, R. S. C., Llewellyn, C. C. (1983). The rapid determination of algal chlorophyll and carotenoid pigments and their breakdown products in natural waters by reverse phase high-performance liquid chromatography. Anal. chim. Acta. 151: 297-314

Neale, J. P., Cullen, J. J., Yentsch, C. M. (1989). Bio-optical inferences from chlorophyll a fluorescence: What kind of fluorescence is measured in flow cytometry? Limnol. Oceanogr. 34: 1739-1748

Neubauer, C., Schreiber, U. (1989). Photochemical and nonphotochemical quenching of chlorophyll fluorescence induced by hydrogen peroxide. Z. Naturforsch. 44C: 262-270

Ögren, E., Oquist, G. (1984). Photoinhibition of photosynthesis in Lemna gibba as induced by the interaction between light and temperature. III. Chlorophyll fluorescence at 77 K. Physiologia Plant. 62: 193-200

Owens, T G., Gallagher, J. C., Alberts, R. S. (1987). Photosynthetic light-harvesting function of violanxanthin in Nannochloropsis spp. (Eustigmatophyceae). J. Phycol. 23: 79-85

Perry, M. J., Talbot, M. C., Alberte, S. A. (1981). Photoadaptation in marine phytoplankton: response of the photosynthetic unit. Mar Biol. 62: 91-101

Powles, S. B. (1984). Photoinhibition of photosynthesis induced by visible light. A. Rev. Plant Physiol. 35: 15-44

Prézelin, B. B., Sweeney, B. M. (1978). Photoadaptation of photosynthesis in Gonyaulax polyedra. Mar. Biol. 48: $17-35$

Richardson, K., Beardall, J., Raven, J. A. (1983). Adaptation of unicellular algae to irradiance: an analysis of strategies. New Phytol. 93: 157-191

Riper, D. M., Owens, T G., Falkowski, P. G. (1979). Chlorophyll turnover in Skeletonema costatum, a marine plankton diatom. Plant Physiol. 64: 49-54

Sakshaug, E., Demers, S., Yentsch, C. M. (1987). Thalassiosira oceanica and $T$ pseudonana: two different photoadaptational responses. Mar. Ecol. Prog. Ser 41. 275-282

Sukenik, A., Wyman, K. D., Bennett, J., Falkowski, P. G. (1987). A novel mechanism for regulating the excitation of photosystem II in a green alga. Nature, Lond. 327: 704-707 
Therriault, J. C., Booth, D., Legendre, L., Demers, S. (1990). Phytoplankton photoadaptation to vertical excursion as estimated by an in vivo fluorescence ratio. Mar. Ecol. Prog Ser. 60: $97-111$

Vincent, W F. (1979). Mechanism of rapid photosynthetic adaptation in natural phytoplankton communities. I. Redistribution of excitation energy between photosystem I and II. J. Phycol. 15: 429-434

Vincent, W. F. (1980). Mechanisms of rapid photosynthetic adaptation in natural phytoplankton communities. II. Capacity for non-cyclic electron transport. J. Phycol. 16 $568-577$

This article was submitted to the editor
Vincent, W. F., Neale, P. J., Richerson, P. J. (1984). Photoinhibition: algal responses to bright light during diel stratification and mixing in a tropical alpine lake. J. Phycol. 20: 201-211

Weis, E., Berry, J. A. (1987). Quantum efficiency of Photosystem II in relation to 'energy' dependent quenching of chlorophyll fluorescence. Biochim biophys. Acta 894: $194-208$

Yamamoto, H. Y., Takeguchi, C. A. (1972). Concepts on the role or epoxy carotenoids in plants. In: Forti, G. et al. (eds.) Proc. Ind Int. Cong. Photosynthesis, Stresa 1971. W. Junk N. V., The Hague, p. 621-627

Manuscript first received: April 9, 1991

Revised version accepted: July 22, 1991 